\title{
Dear Diary, Dear Comrade: The Diaries of Setske de Haan, Joop ter Heul and Anne Frank
}

\section{Monica Soeting}

\section{INTRODUCTION}

Numerous articles and books have been written about the Diary of Anne Frank-the Royal Library in The Hague alone lists more than three hundred publications. Two of the best articles have been written by Dutch historian Berteke Waaldijk and by Philippe Lejeune. Why? Because Waaldijk was one of the first scholars to read the different versions of Anne Frank's diary (there are at least three: the original diary, the diary as revised by Anne and the published version from 1947) as the literary product of a writer to be, and because Lejeune did the same and paid tribute to the enormous task Anne's father Otto Frank took upon himself after the Second World War to edit and publish the diary entries of his daughter. Waaldijk in her article argues that "Anne Frank's symbolic value as an innocent victim of fascism should not prevent us from reading her diaries as a literary work," while Lejeune wrote his essay to honour Anne and her father as "two true writers: Anne herself, since it was she, locked up in the Secret Annexe, who transformed her diary into a work of art; and her father, Otto Frank, who used the papers that had been saved to complete, respectfully and intelligently, the work that death had cut short." ${ }^{2}$

In "How Anne Frank rewrote the diary of Anne Frank" Lejeune painstakingly reconstructs the story of the diary or rather diaries: how in April 1944 Anne began to rewrite her diary entries from the autumn of 1942 to the spring of 1944 with the intention of turning them into a novel and how her father used both the original diary entries and Anne's reworked 
text to create Het Achterhuis. Dagboekbrieven van 12 Juni 1942-1 Augustus $1944,{ }^{3}$ which was first published in Amsterdam in 1947. In his signature direct and personable style Lejeune pays tribute to Anne's development as a writer during the two years she was hiding in the annexe of her father's offices at the Prinsengracht in Amsterdam ("the portrait that she draws of her parents' marriage, even if she was wrong about it, is at least indicative of a future novelist full of talent," he writes ${ }^{4}$ ) and her growing insight into human relations. At the same time Lejeune manages to correct the image of Otto Frank as a prude and mean father who deliberately eliminated his daughter's references to sex and her negative remarks about her mother in the published version of the diary. Taking the trouble to read the different versions of the diary as published in the Critical Edition (1989 and 2003) very carefully, Lejeune shows that the opposite is true: in Het Achterhuis Otto Frank put back sentences which Anne had not copied into the version she meant to publish after the war, even when they were painful to him. The sentences Otto Frank did leave out in Het Achterhuis, Lejeune writes, were those that didn't contribute to the overall style of the book.

Trying to piece all the different diary entries and versions together and noting how many entries must have been lost when members of the German Sicherheitsdienst (SD) ransacked the annexe on August $4^{\text {th }}$ 1944, Lejeune also tried to reconstruct the history of the diary and its different spin offs as conclusively and accurately as possible. However, in his conclusion of "How Anne Frank rewrote the diary of Anne Frank", Lejeune states that the investigations which he started in 1989 were necessarily incomplete as not all Anne's writings have been translated from Dutch into French or English. This is indeed a problem for all scholars who do not read Dutch yet wish to comprehend the many layers of Anne Frank's diary entries and especially for those who, like Lejeune, wish to investigate their literary aspects. The biggest problem is that Anne's favourite novels, the four parts of the Joop ter Heul-series, written by Dutch author Cissy van Marxveldt (pseudonym of Setske de Haan, 1889-1948), which, as Waaldijk shows, had a "direct and important influence on Anne", ${ }^{5}$ have never been published in any other language than Dutch. ${ }^{6}$ In my tribute to Philippe Lejeune and his acknowledgement of the story of the Diary of Anne Frank as being "at once awful, complicated, beautiful, and paradoxical", I will not only show how the form and content of the Joop ter Heul-series shaped Anne's diaries, but also how Van Marxveldt's own diary found its way into Joop ter Heul's and from there into the diary of Anne Frank. ${ }^{7}$ In order to do so, I will first reflect on Van Marxveldt's diary and the content and history of the Joop ter Heul-series. 


\section{"I CAN ENTRUST YOU WITH EVERYTHING"8}

On July 23 ${ }^{\text {rd }} 1908$ the parents of eighteen year old Setske de Haan presented their daughter and only child with a diary-not a special kind of diary with a velvet cover and a little lock but a sturdy, hardcover copybook. On the first page Setske's father, who at the time was head teacher of the elementary school of the affluent Frisian village of Oranjewoud, had copied a Frisian poem; an adaptation of "Memme Seine" (mother's blessing) by the Frisian author S.S. Koldijk (1861-1927). Above the poem he had written, in Frisian: "Bij "t ôfskie", at parting. The diary was indeed a parting gift as Setske was about to leave for Coventry in England, where she was going to work as a lady's companion for a certain Mrs. Ellis. Or so she thought.

The diary Setske received from her parents initially served the same purpose as most other diaries. ${ }^{9}$ Setske used it to record what she had done, thought and felt during the past day, whether she had acted rightly or wrongly and used her time wisely. She dedicated her diary to her father, which implies that she also meant to use the diary as an account for her parents of her daily life in Coventry. Most of all Setske used her diary, which she addressed as "dear comrade", as a much needed outlet for her anger and frustration.

The first written pages of the diary show that Setske had had undue expectations of her job at the Ellis family-the very first pages had been cut out by Setske at the beginning of August 1908, as they "spoke of too much sorrow". ${ }^{10}$ The Ellis family consisted of Dr Ellis, a general practitioner, his wife, who was pregnant, their two-year-old daughter Molly and two servants. When Setske applied for the job, she probably had the images of lady's companions in popular novels in her mind, such as the noble Irene von Meltzow, the main character of Omhoog! (original title: Empor!), a novel written by the German writer Ida Boy-Ed, which she may have read, as it was published as a serial in a popular Dutch newspaper. When Irene's father, a widower, marries a woman of Irene's age, Irene decides to leave the family home and take a job as a companion to the wife of a wealthy merchant. As a lady's companion Irene doesn't have to do anything other than to be present, converse with her employer and occasionally do some light sewing. Irene hates her uncivilized employer - a typical upstart-but at the end of the novel she is rewarded for her perseverance and patience when she marries the noble son of the merchant couple, who is a famous physician. Setske may also have read other newspaper series published around that time about lovely and sensible young women who travel as ladies' companions to the Riviera or play important roles in the lives of noble families. 
Whether Setske was influenced by novels like those of Boy-Ed or not, she expected she would play the piano with her employer, converse in French and read novels to her. Instead she had to take care of Molly, a spoiled little girl who seems to have been an expert in generating negative attention. ${ }^{11}$ In addition, Setske was given light household tasks, such as dusting and shopping. Although this greatly upset Setske, this seems to have been customary at the time, judging from the many advertisements which appeared in newspapers at the beginning of the twentieth century. Like one in the Dutch journal Nieuws van de Dag (News of the Day) of February $13^{\text {th }}, 1907$ : "A teacher, 44 years old, seeks employment as a companion or a housekeeper at household in family without children." Or another one in De Tijd (The Times) of April 25 ${ }^{\text {th }}$, 1908: "R.C. young lady, aged 27, wishes to be placed as a companion and assistant in the household. Knowledge of French, German and English language, music and household activities." Setske, however, felt most horribly insulted when she was told to dust rooms and do the shopping. In addition, Mrs. Ellis insisted Setske should dress and hold herself in a more sophisticated manner than she as a village girl was used to, which made her feel inferior to boot.

Setske vented her anger at Mrs. Ellis in her diary. At the same time, she used her diary - and her anger-to determine her preferred identity. In her daily notes she presented herself as a down-to-earth, frank, honest and brave Frisian, the antitype of the frivolous, affected and snobby Mrs. Ellis, as described by Setske in a diary entry on September $2^{\text {nd. }}$

\footnotetext{
Madam came downstairs to dine and was very annoying, well, this may be attributed to her illness [her pregnancy, MS]. After dinner she took me upstairs, where she showed me all her treasures, such as stockings, underwear, blouses, etc. Well, I was very impressed by everything and it was really worth the effort, but not really. I never know how she keeps everything apart. Only seven pairs of stockings for morning, afternoon and evening ba-ba, such a hassle! $!^{12}$
}

Undoubtedly Setske felt insulted and jealous. As the daughter of an ambitious headmaster, whose own and his wife's parents had all been labourers, but who in Oranjewoud was a member of the new middle class, Setske felt degraded at Mrs. Ellis's demeaning remarks about her clothes and manners. She therefore presented herself in her diary as the courageous and proud daughter of the headmaster of beautiful Oranjewoud-once founded by the princely Nassau family-who would show her worth to all the Mrs. Ellises of the world. "Be strong, and be good," she wrote in English on August $17^{\text {th }} 1908$, was going to be her motto. ${ }^{13}$

Setske's diary had yet another function: she also used it to practise writing. After she resigned her job with the Ellis family at the end of August 
1908, she moved into a girls' boarding school in Bath. Here she had the time of her life. For the first time, she confided to her diary, she loved to study. She also loved her teachers and her fellow students and delighted in field trips and going to concerts and plays. Her parents, who must have struggled to pay Setske's school fees, decided that his was the time for her to prepare for her future. Her father wanted her to become an English teacher. Setske, however, had other plans. On November $22^{\text {nd }}, 1908$, a few days before her nineteenth birthday, she noted:

And now on Tuesday I will be 19 and my wish that I may once write a book becomes more fervent by the day. Oh, to write a book-I can imagine how wonderful it must be to be able to write a book and I just feel that I will be able to do so one day. ${ }^{14}$

Several entries in Setske's diary are clearly written in the form of a story. These entries are carefully styled and actually quite witty; it's obvious she took great pains in composing them and enjoyed doing so. Being a writer, Setske decided, would also give her the ultimate opportunity to take revenge on Mrs. Ellis. "I hope to write a book once," she wrote on November $22^{\text {nd }}$, "and tell the truth about my life, my two months' life with you and your sweet brat and it will fill a whole book and you will not play a great role in it, Mrs. Ellis!"15

Setske kept her promises. In 1916, shortly after her marriage to Amsterdam-born Leon Beek, she started writing short stories which were published in different popular Dutch magazines, like Panorama. In 1917 she published her first two novels Game-and Set! and Het hoogfatsoen van Herr Feuer (The decency of Herr Feuer), which were followed by 23 novels and collections of short stories. One of her last novels, a fifth sequel to the Joop ter Heul-series, was published in 1945, three years before Van Marxveldt's death in 1948. ${ }^{16}$ In 1931 Van Marxveldt published Puck van Holten, a story about the daughter of a retired headmaster in Friesland. Puck has accepted a job as a lady's companion in Coventry, and Mrs. Ellis, who is renamed Mrs. Cunningham in the novel, does indeed play a role in the novel and not a very nice one. Mrs. Ellis as Mrs. Cunningham is egotistical and cruel. She is jealous of her pretty and genteel employee, who is conspicuously more patient and indeed more genteel than Setske seems to have been in Coventry. Like Setske, Puck is told to take care of Dr. and Mrs. Cunningham's spoiled little daughter and do household chores. But unlike in real life Molly, as little Millicent Cunningham, loves Puck much more than she loves her own mother, as Puck, unlike Mrs. Cunningham, is sweet, wise and caring. In this sense Puck van Holten, like many more of Van Marxveldt's novels, can be seen as a form of autobiografiction, as defined by Max Saunders. ${ }^{17}$ Van Marxveldt reworked her 
autobiographical writings-her diary-not only to rewrite her personal history and to retaliate against Mrs. Ellis but also to present herself as the upper-middle-class woman she yearned to be, depicting her alter ego Puck according to the then upper-middle-class ideal of women as caring wives and mothers. ${ }^{18}$

\section{THE DIARY OF JOOP TER HEUL}

Although Van Marxveldt copied quite a few notes from her 1908 diary into Puck van Holten, she didn't write this novel in the form of a diary. She did use this form In De H.B.S.-tijd van Joop ter Heul (The high school time of Joop ter Heul), the first part of a five-part series, which was first published in 1919. Although this book initially did not receive much attention in the press, a second edition appeared within a few months. The reviewers who did discuss the novel emphasized the recognisability of Joop's experiences for high school girls, which was validated by the many fan letters Van Marxveldt received ${ }^{19}$ and by several surveys conducted in the thirties. ${ }^{20}$ Since 1919 numerous editions have been published; the printing of the latest edition has been scheduled for autumn 2018.

Other than in Puck van Holten, Van Marxveldt did not copy her own diary entries in the parts of the Joop ter Heul-series. However, the series are autobiografiction in that they mirror Van Marxveldt's social aspirations. Van Marxveldt would use every opportunity to convince her readers that she was a member of the same upper-middle-class as Joop and her rich family belong to. Better yet, in interviews in newspapers and magazines, and in an autobiographical essay published in 1930, she insisted that she 'was' Joop, that Joop's father 'was' her own father and that she lived in the same neighbourhood where the series was situated. Yet the link between Van Marxveldt's Joop ter Heul-series and Anne Frank's diary is not to be found in the fulfilment of both their wishes-being a writer, finding fulfilment of their ambitions in writing-but in a diary. Not Van Marxveldt's diary, but Joop's, as written by Van Marxveldt in the style she had developed in her own diary: direct, witty and with an eye for detail and a sense of perspective.

Joop is the daughter of a rich business man and his snobby, upper class wife. The family consists of the two parents, the equally snobbish eighteen-year-old Julie, sixteen-year-old Kees and fifteen-year-old Joop. Two maids take care of the household. Joop is a pupil at a girls' high school and like many other characters in novels for girls from this time, Joop is a jongensmeisje, a tomboy. She hates school, loves playing pranks with her friends and smoking cigarettes in the school's bicycle shed. She declares she'd rather be a butcher's delivery boy, riding her bike through 
Amsterdam and scaring pedestrians. The first chapter of the novel starts with a letter from Joop to Nettie, a school friend who has moved from Amsterdam to another, undisclosed town in the Netherlands. "Dear Net," it says at the top of the letter, followed by a famous phrase: "I have been fretting ever so long, before I truly started this epistle, because Julie said, that you should never start a letter with 'I'", followed by an explanation:

Julie always considers these matters ever so seriously; Kees says that she is making it into a matter of conscience. You know, I think it's all very silly, but since I heard it from Julie, I wanted to be comme-il-faut for a change. And really it's so strange, I knew of lots of salutations, but they all started with "I". Anyway now you know, that I know, how it is supposed to be. What a fuss, right? I am sure you couldn't care less either. Well, here we go actually! I really like the word "actually", just like "notwithstanding"; it fills up space so wonderfully in an essay. I always work with them, wherever I can. I would really recommend it. ${ }^{21}$

Next, Joop tells Nettie about a club she wants to found with her friends. In the following letters Joop explains to Nettie that her father has forbidden her to join the club, because her school results are too bad. Therefore she has become an honorary member and secretly participates in the preparations for a play that the club wants to perform. When her father finds out, she is grounded on her free afternoons. From now on she will have to do her homework in her father's office and she is allowed to write her letters to Nettie on Sundays only.

Chapter two is not written as a letter, but neither as a diary entry. In this chapter Joop explains that her father has caught her while writing a letter to Nettie when she was supposed to be doing her homework. As a result, she is forbidden to write any letters at all. That same evening Joop starts writing a secret diary in an old notebook from Julie:

I am in our bedroom, writing next to a candle. I bought it for three cents from Mina [one of the maids]. It's almost eleven o'clock and I think Julie will soon come home. So, now I have inaugurated my diary. I have started it in a French exercise book of Julie's. In her last exercise she had twenty five mistakes. So she never will have to attack me in French ever again, because I will tell her at once that she never was able to make decent exercises.

It's as if I have been talking to Net. And strangely, I am completely over my anger. ${ }^{22}$

The next paragraph is also written in the form of a diary entry and states both date and time: "December $16^{\text {th }}$, a quarter past ten in the evening." This date and time schedule is kept in the rest of the novel. However, the story ends with a letter to Nettie, dated "Sunday morning, July $19^{\text {th }}$, 
ten o'clock" (284). In this last chapter, all members of the Jopopinoloukico club (the club's name, composed of the first two letters of the first names of the club members: Joop, Pop, Pien, Noortje, Loukie, Kitty and Connie) and Miss Wijers, who has prepared Joop for her final exams, tell Netty how Joop's father has invited them to a holiday aboard a ship as a graduation gift.

The diary formula proved to be a big hit. ${ }^{23}$ Thanks to the linear form and the accurate markings of date and time, the four pre-war parts of the Joop ter Heul-series seem to be playing in real, measurable time. Moreover, Joop does not have to mince words in her diary, which she keeps in a lockable cupboard. This means she can use words that do not appear in most novels for girls at the time, even though Joop puts the more vulgar expressions, such as "drop dead", in Kees's mouth. The many inappropriate words and tomboy phrases must have made the series extra exciting for Van Marxveldt's young readers.

More importantly, in her diary Joop expresses in her own words and as "honestly" as possible what she has experienced during the day. Joop as character-narrator is not only a telling subject who comments and acts as an omniscient narrator, but is the focaliser as well. Van Marxveldt also makes good use of the contrast between different times. In sentences like "And then I-oh, here is Mina with a cup of cocoa. I will stop writing right away because there is nothing new to tell", ${ }^{24}$ Joop changes from the past to the present tense and from narrator to experiencer. This gives the reader the illusion that she has immediate access to Joop's "real" life, which also means the diary notes are experienced as authentic.

Another part of the attraction of the novel was the environment in which the Joop ter Heul-series are situated. According to the references to the different street names in the novel the Ter Heul family lives in a villa near the Vondelpark in Amsterdam, a neighbourhood where only rich people could (and still can) live. This must have made the series just as desirable for Van Marxveldt's young middle-class readers ${ }^{25}$ as the character Leo van Dil, a young, rich, smart and handsome Amsterdam banker, who makes his appearance in the second part of the series and becomes Joop's husband in the third part after several comical misunderstandings.

\section{FAN FICTION}

The diary of Joop ter Heul inspired countless high school girls to re-enact the story, especially after scenario writer and actor Dom de Gruyter had turned the series into a stage play. The premiere of the play took place in The Hague in December 1924. Julia de Gruyter, the then thirty-sevenyear-old wife of Dom de Gruyter, played Joop. After seeing the piece, 
at least one group of high school girls from The Hague re-enacted the adventures of the Jopopinoloukicoclub in a form of fan fiction avant la lettre. The girls also decided to honour Julia de Gruyter with a fan letter. Because they did so under their club names and addressed De Gruyter as "Joop", an intricate back-and-forth of letters in a mock Joop ter Heulstyle ensued. Thus "Joop" from The Hague would write to the stage-Joop about the character Joop. In this correspondence fiction and non-fiction merged, as the following excerpt from a letter from The Hague to De Gruyter dated January $26^{\text {th }}, 1925$ shows:

Dear Joop,

You do not think it's absurd, do you? That we send you a letter? If you say no, I'll explain to you why we are doing so.

At the moment I am sitting in my room to write this letter which we composed this afternoon after school. We were sitting on the windowsill of a cheese shop which is deliciously wide. The whole club could sit on it. They were all screaming what I had to put in the letter and at last I had no idea what I should write. But... as there is an end to everything there is an end to this. And now I am sitting here, not being at my best, but that is because I still have to stamp a lot of history into my brain. And when I think of that my energy disappears.

[...] Please say hi to Leo. By the way, our accountant plays Jog [Julie's husband]. You should really wear the same little dresses, they suit you like they suit Julie. Well goodbye. A handshake from your Joop. ${ }^{26}$

Some sixteen years later, in 1941, two Amsterdam girls also identified with Joop ter Heul: twelve-year-old Jacqueline van Maarsen and her friend of the same age Anne Frank. The series belonged to their favourite books, as Van Maarsen states in Ik heet Anne, zei ze, Anne Frank (My name is Anne, she said, Anne Frank). Jacqueline and Anne, like the members of the fan club in The Hague, re-enacted scenes from the series. Jacqueline's and Anne's favourite scene was one from the second last chapter of part two of the series, which was first published in 1921. In this scene Joop is kissed by Leo for the first time. Because Joop has never before kissed a man she feels "terribly shy". When Leo tells her she is the sweetest creature in the world and demands a reward for this, she offers him a kersenbonbon, a cherry liquor chocolate:

\footnotetext{
"Naughty girl, just give it to me."

"But you don't like them."

"This one I like. And when I've eaten it, what else will I get?"

"Another kersenbonbon. Or a marron glacé," I proposed.

Leo screwed both my hands into his.

"Don't tease me now. What will I get?"
} 
"I've never kissed a man before," and I blushed desperately. "Except for the Piepert [Joop's father]. And Jog once, on his nose."

"Oh, it doesn't matter at all, even though you are awkward. Come here Joop, and be sweet."

And I put my head on his striped jacket and I was sweet. ${ }^{27}$

According to Van Maarsen's memoirs, Anne and she would act as Joop and Leo alternatively, to their great pleasure and delight.

\section{HET ACHTERHUIS}

In June 1942, Anne Frank spotted a diary in the window of bookshop Blankevoort in the Zuider Amstellaan (the present Rooseveltlaan), just around the corner from the Merwerdeplein, where she lived. This was the diary she received as a birthday present from her parents on June $12^{\text {th }}$ 1942. On that very day Anne wrote on the first page of her new diary: "I hope I shall be able to confide in you completely, as I have never been able to do in anyone before, and I hope you that will be a great source of comfort and support to me." 28 This is a usual kind of inscription, comparable to the one Setske de Haan had written in her diary: "My dear diary, you will become my faithful companion in this foreign county. I will entrust everything to you, the pleasant and the sad will fill your white pages [...]. Dear diary, we will become friends." ${ }^{29}$

For Anne, as for Setske, her diary was more than a journal in which she kept track of what she had done. Anne's diary was, like Setske's diary, also meant as a confessor. And like Setske, Anne also used her diary to practise writing. On 5 April 1944 Anne, just as Setske had done thirty-six years earlier, confided to her diary that she wanted to become a writer:

I must work, so as not to be a fool, to get on, to become a journalist, because that's what I want! I know I can write, a couple of my stories are good, my descriptions of the "Secret Annexe" are humorous, there's a lot in my diary that speaks, but -

Whether I have real talent remains to be seen. ${ }^{30}$

On 11 May 1944 she repeated her wish:

Now about something else: you've known for a long time that my greatest wish is to become a journalist some day and later on a famous writer. Whether these leanings towards greatness (insanity!) will ever materialize remains to be seen, but I certainly have the subjects in my mind. In any case, I want to publish a book entitled het Achterhuis after the war, whether I shall succeed or not, I cannot say, but my diary will be a great help. ${ }^{31}$ 
Anne also fulfilled her promise. On May 20 1944, she reported that she had started rewriting her diary on loose sheets. This was the beginning of what was to be the novel Het Achterhuis. When the eight people in hiding in the secret annexe of the office on the Amsterdam Prinsengracht were discovered by the Sicherheitsdienst in August 1944, Anne had rewritten her diary up to March $29^{\text {th }} 1944$.

In June 1947, the diary was published under the title Het Achterhuis, just as Anne had hoped it would be published. However, almost nobody at that time and in the years to come read the text as a novel, as Anne had intended. The historian Jan Romein, who was one of the first to review the book, concluded that Anne would have become "a gifted writer if she had continued to live", but regarded the published diary as an expression or "De profundis" of one of the worst crimes ever committed: the persecution of the Jews. ${ }^{32}$ The historian Annie Romein-Verschoor also recognized Anne's literary talent, but classified the diary in her introduction to the first edition of Het Achterhuis as a war document:

A document of the cruelty and sad misery of the persecution of the Jews, of human helpfulness and betrayal, of human adaptations and non-adaptation; the small joys and great miseries of the people in hiding have been described in a direct, non-literary and therefore excellent manner by this child who in any case had the one important quality of a great writer: to remain uninhibited, not to be blind to things as they are. ${ }^{33}$

More importantly, Romein-Verschoor regarded Anne as a symbol of an innocent creature that blossoms for a short time before it gets stifled:

But the most important thing about this diary is not for me the documentation $[\ldots]$. When, in the tropics, a young plant is taken from the temperate mountain climate to the hot plains, it blooms richly and lavishly one last time before it is destroyed. [...] Just like the little brave geranium which has stood flowering and blooming behind the shuttered windows of the annexe. ${ }^{34}$

The interpretation of Anne Frank's diary as a document of the persecution of the Jews and Anne herself as a symbol of innocence dominated for a long time, contrary to Anne's wish and intention. Berteke Waaldijk was one of the first to point this out. In "Reading Anne Frank as a Woman", she investigated Het Achterhuis via stylistic and intertextual references to enable a revaluation of the literary qualities of Anne's writings. In doing so, she came to the conclusion that Anne had been influenced by one author in particular: Cissy van Marxveldt.

As Van Maarssen demonstrates, Anne adored Van Marxveldt's novels. But praise for Van Marxveldt's books can also be found in Anne's diary. 
On September 21 1942, Anne wrote: 'Mr. Koophuis brings a few special books for me every other week. I'm thrilled with the Joop ter Heul-series. I've enjoyed the whole of Cissy van Marxveldt very much. And I've read Een zomerzotheid ${ }^{35}$ four times and I still laugh about some of the ludicrous situations that arise.' And on 14 October 1942: 'Yesterday I finished [De Stormers]. It's quite amusing, but doesn't touch Joop ter Heul [sic]. As a matter of fact, I think Cissy van Marxveldt is a first-rate writer. I shall definitely let my children read her books. ${ }^{36}$

There are many more references to Joop ter Heul in Anne's diary. Joop's friends and girlfriends regularly appear in Anne's diary, as in her letter to Kitty of 27 September 1942, which is addressed to Joop's friends Pop, Pien, Loutje and Connie. In a letter addressed to Kitty and dated 28 September 1942, she asks Kitty to greet Kees ter Heul, Ru Duyff (Connie's boyfriend), Kaki Kruivers (Loutje's boyfriend) and Kitty Franken, another club member.

Waaldijk also points to phrases inspired by the Joop ter Heul-series, like a sentence about the inappropriate use of 'I' at the beginning of a letter (dated 19 January 1944) and the sudden transitions from the past to the present tense. Anne, however, took her diary to a next level by writing about menstruation and sex, ${ }^{37}$ issues that are only referred to glancingly in the Joop ter Heul-series, even though many young readers, like Jacqueline and Anne, found the 'kersenbonbon-scene' in the second part of the series titillating. Unlike Van Marxveldt, ${ }^{38}$ Anne wrote in favour of the emancipation of women, even though Joop is more emancipated than one would think at first glance, as she only seemingly "obeys" her husband Leo and mocks traditional ideals of womanhood throughout the series. ${ }^{39}$ Yet, even though many scholars have criticised the "sanctification" of Anne Frank as a pure and innocent victim, little short of a virgin saint who has redeemed us from the wrongdoings during the Second World War, ${ }^{40}$ almost none of them have recognised Anne as the writer she was. All in all, Waaldijk concludes her article,

\footnotetext{
one of the things I can do to honour Anne Frank is to read her as the writer she wanted to be and the writer she was. Modern readers need to acknowledge that Anne Frank's thinking and writing were heavily influenced by the texts available to her. Instead of considering this influence a contamination, we can admire the way Anne gave these texts new meaning and transcended them. Purity and innocence are metaphors of virginity that do not apply to Anne Frank's writing. ${ }^{41}$
}

This brings us back to Lejeune. Echoing Waaldijk, in the last paragraph of his article on Anne Frank's Diary Lejeune ascertains that "generally speaking, it seems as though Anne Frank's story prevents people from 
reading her diary as a text" ${ }^{42}$ Referring to the influences of the Joop ter Heul-series on Anne's diary, he too honours Anne Frank as an author. What at the beginning of the diary was a "vague project," he writes, "[became] a structured, continuous text whose virtual literary status is indicated by reference to Joop ter Heul". ${ }^{43}$

Unlike most other scholars, however, Lejeune also carefully analysed Otto Frank's editing of his daughter's original diary and the rewritten diary entries to produce Het Achterhuis. Dagboekbrieven van 12 Juni 1942-1 Augustus 1944. Thus Lejeune comes to the conclusion that the parts that were left out-mostly referring to sex but also to her parent's marriage - were not banned from the published edition by Anne's father, as Waaldijk and other authors-e.g. Cynthia Ozick ${ }^{44}$ - presumed, but by the editors of the publishing house which published the first edition of Het Achterhuis, and because of opposition by other members of the Frank family. ${ }^{45}$

Lejeune also analysed the three diary pages that Otto Frank gave to a Dutch man, Cor Suyk, who in his turn turned them over in 1998 to the then Netherlands Instituut voor Oorlogsdocumentatie (NIOD) ${ }^{46}$ These unnumbered, undated and unfinished entries speak about the marriage of Anne's parents and contain a passage in which Anne states that she wants nobody to read her diary, and certainly not her family-and yes, these have been deliberately left out of the published diary by Otto Frank. According to Suyk, Otto Frank handed them over to him because he wanted to be telling the truth when asked if he had kept any parts of the diary to himself and answering that he hadn't. However, that doesn't mean Otto Frank left Anne's statement about her diary being secret out of the published version, as Lejeune points out. ${ }^{47}$ "I'm not planning to let anyone read this stiff-backed notebook grandly referred to as a 'diary'," Anne wrote on June $20^{\text {th }} 1942$, eight days after she had turned thirteen, and this sentence has been in the published diary since 1947. The only thing Otto Frank left out was the additional "least of all my family", which was added on one of the three pages.

Maybe Lejeune is one of the very few authors-if not the only onewho appreciates Otto Frank's position as the editor of his daughter's journal:

What is troubling [...] is that the father felt troubled. But just think what he went through! What an awful trial it was for him to read, in 1945, the notebooks that would have remained secret if Anne had lived. It was not his place to read them, and it was a sign that she was dead, and yet it was his place, to make sure that the book she had been planning was published, and to keep her alive! The only additional thing in the draft is the (very kind and natural) reference to "Father, Mother and Margot" as excluded addressees. 
So yes, those words continued to hurt him, even though $[\ldots]$ there was no real cause for hurt. And in that lies his greatness.

Thus, Lejeune's reading and rereading of the three versions of Anne Frank's diary, have become a tribute to Anne as well as to Otto Frank. With Anne's love for her father in mind-a love she shared with Van Marxveldt and Joop ter Heul, who also admired their fathers and seem to have loved them more than their mothers ${ }^{48}$ - Lejeune's reflections are as much a tribute to Anne and Otto Frank as a marker of his own sensibility, his inimitable writing style and his great sense of empathy. By carefully depicting his own reading of Anne Frank's diary, he, like Van Marxveldt and Anne Frank, suggests an intimacy between himself and his readers by changing from past to present tense in the same sentence. When he learned that a new edition of the diary had been published he changed from perfect to past tense: "I wrote that section in 1990. Today I have to add a postscript: a new edition of the diary of Anne Frank has come out since then!" 49 And when he has learned about Suyk's revelation that he has safeguarded three diary pages for Otto Frank, he informs us of his surprise in the present tense: "A dramatic turn of events. An incredible but predictable new development: the 'definitive' edition is not definitive!"50

Even more appropriately, he ends his article with a diary entry, completing the circle of the related diaries of Setske de Haan, Joop ter Heul and Anne Frank. "As I reread my whole study," he wrote in 2001, "I see that there are two directions in which to take my research: on the loose pages [of Anne's diary], to get as closely as possible to the mystery of their composition; and, on a more personal level, an autobiographical reflection on why I identify so passionately with Otto Frank." 51

"Anne Frank's words will be part of the texts that influence millions of readers' feelings and writings, not only because of her symbolic value as a victim of fascism, but also because of the text's value as a mode of writing for women writers": thus Waaldijk ends her article on Anne Frank's diary. In a different context, the same can be said about Philippe Lejeune. His writings have become, over fifty years, a model for scholars writing not just on Anne Frank's diary, but all diaries.

\section{WORKS CITED}

Boy-Ed, Ida. Empor! Hamburg: Igel Verlag, 2008 [1892].

Daalder, D. L. Wormcruyt met suycker. Historisch-critisch overzicht van de Nederlandse kinderliteratuur met illustraties en portretten. Schiedam: Interbook International, 1976 [1935]. 
Frank, Anne. De dagboeken van Anne Frank. Ingeleid door David Barnouw, Harry Paape en Gerrold van der Stroom; met de samenvatting van het rapport van het Gerechtelijk Laboratorium, opgesteld door H.J.J. Hardy. Tekstverzorging door David Barnouw en Gerrold van der Stroom. Amsterdam: NIOD/Bert Bakker, 2001.

Goedkoop, Hans. "Een morele schijnbeweging. De biografie van een joods meisje als onderzoek naar de shoah." De vele gezichten van Anne Frank. Visies op eenfenomeen, Samengesteld en ingeleid door Gerrold van der Steen. Antwerp/Amsterdam: De Prom, 2003. 244-253.

Lejeune, Philippe. "How Anne Frank Rewrote Anne Frank.” Ed. Philippe Lejeune. On Diary. Honolulu: University of Hawai'i Press, 2009. 237-267. Edited by Jeremy D. Popkin and Julie Rak. Translated from the French by Katherine Durnin.

Marxveldt, Cissy van. De H.B.S.-tijd van Joop ter Heul. Amersfoort: Valkhoff \& Co., 1919.

Marxveldt, Cissy van. Joop ter Heul's problemen. Amersfoort: Valkhoff \& Co. 1921.

Marxveldt, Cissy van. De Stormers. Amersfoort: Valkhoff \& Co., 1925.

Marxveldt, Cissy van. Een Zomerzotheid. Amersfoort: Valkhoff \& Co., 1927.

Marxveldt, Cissy van. De Arcadia. Een genoeglijke reis naar Spitsbergen. Amersfoort: Valkhoff \& Co., 1928.

Marxveldt, Cissy van. Confetti. Valkhoff \& Co., 1930.

Marxveldt, Cissy van. Puck van Holten. Amersfoort: Valkhoff \& Co., 1931.

Marxveldt, Cissy van. Lief dagboek, beste kameraad. Diary, transcribed and introduced by Monica Soeting. Bloemendaal, 't Schaep, 2017.

Ozick, Cynthia. "The Misuse of Anne Frank's Diary.” The New Yorker, October 6 ${ }^{\text {th }}, 1997$. https://www.newyorker.com/magazine/1997/10/06/who-owns-anne-frank. Accessed on May $3^{\text {rd }} 2018$.

Pattynama, Pamela. "Van een balorige élève en een keurige huisvrouw. De Joop ter Heul-serie van Cissy van Marxveldt.” Eds. Aafke Boerma, Erna Staal and Murk Salverda. Bab's bootje krijgt een stuurman. De meisjesroman en illustrator Hans Borrebach. Amsterdam: Querido 1995. $8-30$.

Saunders, Max. Self Impression Life-writing, Autobiografiction, and the Forms of Modern Literature. Oxford: Oxford University Press, 2010.

Soeting, Monica. Cissy van Marxveldt. Een biografie. Amsterdam: Atlas Contact, 2017.

Van Lith-van Schreven, M. A. E. van. "Het Europese kind in Indië en zijn lectuur." Indisch Vrouwen Jaarboek 1936. Jogjakarta: Kolff-Buning, 1936. 161-187.

Waaldijk, Berteke. "Reading Anne Frank as a Woman." Womens Studies International Forum 16 (1993): 327-335.

\section{ABOUT THE AUTHOR}

Monica Soeting is one of the founders and the journal managers of the European Journal of Life Writing. In 2009 she was one of the founders of the European section of IABA and the Nederlands Dagboekarchief (Dutch Diary Archive) which was the initiator of the founding of the European Diary Archives and Collections (EDAC) in 2015. She was editor in chief of the Dutch journals Biografie Bulletin and Surplus and has taught life writing classes at the universities of Utrecht and Groningen. In 2017 she published Cissy van Marxveldt. Een biografie. She is a reviewer for the Dutch national newspaper Trouw, a member of the advisory board of the Dutch Foundation of Literature and currently working on a biography of Dutch queen Emma (1858-1934). 


\section{NOTES}

1 Waaldijk 1993:328.

2 Lejeune 2009:237.

3 The Annexe. Dairy-letters from June $12^{\text {th }} 1942$-August $1^{\text {st }} 1944$.

4 Lejeune 2009:263.

5 Waaldijk 1993:331.

6 Jeanne-Marie Soeting-Hellinger is currently working on a translation of the series in English.

7 Waaldijk 1993:331-332.

8 This chapter is based on an article which was published in Literatuur zonder Leeftijd in 2017.

9 Lejeune 2009:51-201.

10 Van Marxveldt 2017:15.

11 Unknown to Van Marxveldt, Molly as an adult became a famous actress under the pseudonym Diana Napier. In 1936 she married the then famous Austrian singer Richard Tauber in London. After his death in 1948 she published a biography of her late husband. In 1956 she published her autobiography My Heart and I, which unfortunately does not contain references to her one-time nanny Setske de Haan.

12 Van Marxveldt 2017:54. (My translation, MS).

13 Van Marxveldt 2017:15. (My translation, MS).

14 Van Marxveldt 2017:99. (My translation, MS).

15 Van Marxveldt 2017:99. (My translation, MS).

16 The style of this novel plus the fact that Van Marxveldt was very ill at the time raises the suspicion that it was at least partly written by her son Leo, who published novels under the pen name of Jan van Marxveldt.

17 Saunders 2010.

18 As shown by Nicola Humble, among others.

19 Van Marxveldt 1930. (My translation, MS).

20 Daalder 1935, Van Lith-van Schreven 1936.

21 Van Marxveldt 1919:5.

22 Van Marxveldt 1919:20.

23 Van Marxveldt was not the first to write a novel for girls in the form of a diary. Het klaverblad van vier (The four-leaved cloverleaf) by Dutch author Tine van Berken (1894) was also written as a diary, and this also applies to De jongste thuis (The youngest child of the family) by Albertina Schlüter (1912). Van Marxveldt also used it for the novel Arcadia, which she published in 1928.

24 Van Marxveldt 1919:82.

25 Because of the upper-middle-class setting of the series, it was heavily criticised by socialists reviewers at the time, e.g. by journalist Henriëtte van der Meij in an article in Belang en Recht (1900).

26 Letters from the collection Julia de Gruyter. University Library, University of Amsterdam, Special Collections. (My translation, MS).

27 Van Marxveldt 1921:214-5.

28 Barnouw and Van der Stroom 1989:177.

29 Van Marxveldt 2017:15.

30 Barnouw and Van der Stroom 1989:586.

31 Barnouw and Van der Stroom 1989:647.

32 Van der Stroom, 2003:16. (My translation, MS).

33 Van der Stroom, 2003:21. (My translation, MS). 
34 Van der Stroom, 2003:21. (My translation, MS).

35 A comedy about social class differences, published 1927.

36 Barnouw and Van der Stroom 1989:240. The translators, Arnold J. Pomerans and B.M. Mooyaart-Doubleday, who clearly didn't read the novel, wrongly translated the title as "Assault". "De Stormers", however, refers to the last name of protagonist Judith Stormer and her brother who are twins. After the Second World War the title was changed to Burgermeester's tweeling (Mayor's twins) as the word De Stormers was connoted with Storm, a journal published by the Dutch SS from 1941 to early 1945.

37 The texts written on the two pages covered up by Anne and disclosed by the Anne Frank House, the NIOD and the Huygens Institute on 15 May 2018, also indicate that Anne was practising her hand as a writer in her dairy. They also demonstrate that she had received sex education from her parents. Interestingly, the disclosure unleashed a stream protest mainly on social media, indicating that many still consider Anne as a saint-like icon and her diary as an untouchable relic.

38 The Dutch suffragette movement is mentioned twice in the first part of Joop ter Heul, but only in a derogatory way: three women go to a suffragette meeting, but one is Connie's very bossy mother, the second is the mother of an unpleasant class mate of Joop's and the third is an elderly, unmarried woman.

39 Pattynama 1995.

40 Hans Goedkoop 2003; Cynthia Ozick 1997.

41 Waaldijk 1993:334.

42 Lejeune 2009:265.

43 Lejeune 2009:239.

44 In her 1997 article Ozick wrote: "But the diary in itself, richly crammed though it is with incident and passion, cannot count as Anne Frank's story. A story may not be said to be a story if the end is missing. And because the end is missing, the story of Anne Frank in the fifty years since "The Diary of a Young Girl" was first published has been bowdlerized, distorted, transmuted, traduced, reduced; it has been infantilized, Americanized, homogenized, sentimentalized; falsified, kitschified, and, in fact, blatantly and arrogantly denied. Among the falsifiers have been dramatists and directors, translators and litigators, Anne Frank's own father, and even-or especially—the public, both readers and theatregoers, all over the world. A deeply truth-telling work has been turned into an instrument of partial truth, surrogate truth, or anti-truth. The pure has been made impure-sometimes in the name of the reverse. Almost every hand that has approached the diary with the well-meaning intention of publicizing it has contributed to the subversion of history."

45 Lejeune 2009:260.

46 Now called: Netherlands Institute for War, Holocaust and Genocide Studies (NIOD).

47 Lejeune 2009:261.

48 Identifying with their mothers would arguably have turned Setske and Anne into housewives, not the writers they wanted to be.

49 Lejeune 2009:258.

50 Lejeune 2009:259.

51 Lejeune 2009:265. 